\title{
WSRC-MS-98-00316 \\ Implementation of ISO140001 at the Savannah River Site
}

by

S. L. Marra

Westinghouse Savannah River Company

Savannah River Site

Aiken, South Carolina 29808

R. D. Reeves

A document prepared for ANNUAL MEETING OF AMERICAN CERAMIC SOCIETY at Cincinnati, OH, USA from $5 / 3 / 98-5 / 6 / 98$.

DOE Contract No. DE-AC09-96SR18500

This paper was prepared in connection with work done under the above contract number with the U.S. Department of Energy. By acceptance of this paper, the publisher and/or recipient acknowledges the U.S. Government's right to retain a nonexclusive, royalty-free license in and to any copyright covering this paper, along with the right to reproduce and to authorize others to reproduce all or part of the copyrighted paper. 


\section{DISCLAIMER}

This report was prepared as an account of work sponsored by an agency of the United States Government. Neither the United States Government nor any agency thereof, nor any of their employees, makes any warranty, express or implied, or assumes any legal liability or responsibility for the accuracy, completeness, or usefulness of any information, apparatus, product, or process disclosed, or represents that its use would not infringe privately owned rights. Reference herein to any specific commercial product, process, or service by trade name, trademark, manufacturer, or otherwise does not necessarily constitute or imply its endorsement, recommendation, or favoring by the United States Government or any agency thereof. The views and opinions of authors expressed herein do not necessarily state or reflect those of the United States Government or any agency thereof.

This report has been reproduced directly from the best available copy.

Available to DOE and DOE contractors from the Office of Scientific and Technical Information, P. O. Box 62, Oak Ridge, TN 37831; prices available from (423) 576-8401.

Available to the public from the National Technical Information Service, U. S. Department of Commerce, 5285 Port Royal Road, Springfield, VA 22161. 


\section{DISCLAIMER}

Portions of this document may be illegible electronic image products. Images are produced from the best available original document. 
IMPLEMENTATION OF ISO14001 AT THE SAVANNAH RIVER SITE

Sharon L. Marra and Ronald D. Reeves

Westinghouse Savannah River Company

Savannah River Site

Aiken, SC 29808

A paper for presentation at the 100th American Ceramic Society Annual Meeting in Cincinnati, Ohio, May 3-6, 1998 and for publication in the proceedings. 


\title{
IMPLEMENTATION OF ISO14001 AT THE SAVANNAH RIVER SITE
}

Sharon L. Marra and Ronald D. Reeves

Westinghouse Savannah River Company

Savannah River Site

Aiken, SC 29808

\begin{abstract}
The Department of Energy's Savannah River Site (SRS) in Aiken, SC recently received ISO14001 certification. ISO14001 is an internationally recognized standard that delineates the elements of an effective environmental management system (EMS) and enhances environmental stewardship. SRS preparations for ISO14001 certification involved a comparison of existing programs to the requirements of the standard. Gaps in the program were identified and work initiated to fill those gaps. Primarily, these deficiencies were related to documentation of the SRS EMS and employee training. Certification was granted after an extensive review by a team of independent auditors. The review included personnel interviews, documentation reviews, and work practice observations. An overview of the preparation process as well as the independent review will be presented.
\end{abstract}

\section{INTRODUCTION}

The Savannah River Site (SRS) is a 310 square mile U.S. Department of Energy (DOE) facility located in Aiken, SC bordering the Savannah River. SRS was constructed in the early 1950 's to produce tritium and plutonium, basic materials used in nuclear weapons. The last of five reactors was shut down in the late 1980 's. However, other facilities are operating in support of the current SRS mission to reduce nuclear dangers, clean up the site and manage the wastes SRS has produced. The environmental restoration mission of the site is to clean up 430 waste sites.

One of the largest efforts at SRS is the management and treatment of 30 million gallons of liquid high level radioactive waste. The high level waste system treats the waste into a low and high level waste fraction. The high level waste fraction is then immobilized in borosilicate glass which is poured into stainless steel canisters in the Defense Waste Processing Facility (DWPF). The canisters are ten feet high and two feet in diameter. The canisters are temporarily stored at SRS and eventually will be sent to a federal repository.

In 1995, SRS senior management voluntarily chose to pursue certification to the new ISO14001 environmental management standard. This decision was based on 
the belief that implementing the elements of ISO14001 will increase cost effectiveness and environmental compliance efficiency. In addition, ISO 14001 certification provides evidence, by an independent third party, to stakeholders and regulators that SRS is committed to an environmentally safe site, pollution prevention, environmental compliance, and continuous improvement.

\section{ISO14001}

The International Organization for Standardization (ISO) is comprised of approximately 120 member countries. ISO is an organization that promotes the development of international manufacturing, trade, and communication standards.

ISO14000 is a series of environmental management standards and guidelines. United States agencies that favor ISO14000 as a voluntary standard include the Environmental Protection Agency (EPA), Department of Energy (DOE), Department of Commerce, and Department of Justice. In fact, EPA participated on the team that drafted the standards.

ISO14001 is the Environmental Management System Standard. ${ }^{1}$ It is a voluntary standard containing elements of environmental management systems based on the implementation of good business practices rather than command-and-control compliance. ${ }^{2}$ The basic environmental management system principles or elements are:

- Policy - The organization must define a policy and ensure commitment.

- Planning - The organization must formulate a plan for fulfilling the environmental policy.

- Implementation and Operation - The organization must develop capabilities and support mechanisms necessary to achieve its environmental policy, objectives and targets.

- Checking and Corrective Action - The organization must measure, monitor, and evaluate environmental performance.

- Management Review - The organization must review and continually improve the environmental management system with the objective of improving overall environmental performance.

Once an organization has implemented the elements of ISO14001, self declaration or third party certification can follow. Self declaration means an organization has determined by some evaluation process, other than a registration audit, that it is conforming with all of the requirements of ISO14001. This can be achieved by completing a gap analysis and implementing corrective actions. The gap analysis and corrective actions can be performed by outside consultants or employees with appropriate knowledge.

As an alternative to self declaration, a registrar can certify an environmental management system after an independent team certified by ANSI/RAB performs an ISO14001 audit and recommends certification. This option would add more credibility than self declaration. 


\section{IMPLEMENTATION AT SRS}

Prior to initiating efforts for ISO14001 certification, SRS management needed to define the scope of the certification. SRS could have pursued certification for the entire site or just for individual facilities. Due to the existing programs already being used and the site organizational structure the decision was made to pursue certification of the entire site. The certificate would then include the following organizations: DOE Savannah River, Westinghouse Savannah River Company (WSRC), Bechtel Savannah River Incorporated (BSRI), Babcock \& Wilcox (B\&W) at SRS, British Nuclear Fuels Limited (BNFL) at SRS, University of Georgia, Savannah River Natural Resources Management and Research Institute, GSA at SRS, and Wackenhut Services Incorporated (WSI) at SRS. This management commitment and decision on scope was made in December 1995.

See Figure 1 for a timeline of ISO14001 implementation/certification activities.

\section{Gap Analysis and Correction of Deficiencies}

Once the decision was made to purse ISO14001 certification a 15 member team representing all affected divisions on site was organized in January 1996. A gap analysis was performed over a four month period (see Figure 1) to determine how well existing programs met the ISO14001 standard. The gap analysis showed that SRS already had good environmental stewardship programs in place but enhancements were needed to fully conform to the standard. A conformance plan was put together which identified the actions needed to come into conformance. The following actions were identified:

- Policy - A written environmental policy statement signed by SRS senior management was needed.

- Planning - A new chapter was needed in the Environmental Implementation Plan which summarized environmental aspects of activities. Environmental review aspects needed to be broadened to include facility activities not just project activities. An introduction by the site manager, emphasizing commitment, was needed to enhance the already existing Waste Minimization and Pollution Prevention Plan.

- Implementation and Operation - The Environmental Management System (EMS) needed to be communicated to all site personnel and ISO14001 awareness training was needed. A "road map" describing how documents and programs fit into the EMS was needed.

- Checking and Corrective Action - Development/implementation of procedures for identifying and handling key environmental records was needed. A revision to the existing self assessment program was also needed to assess the environmental management system. 


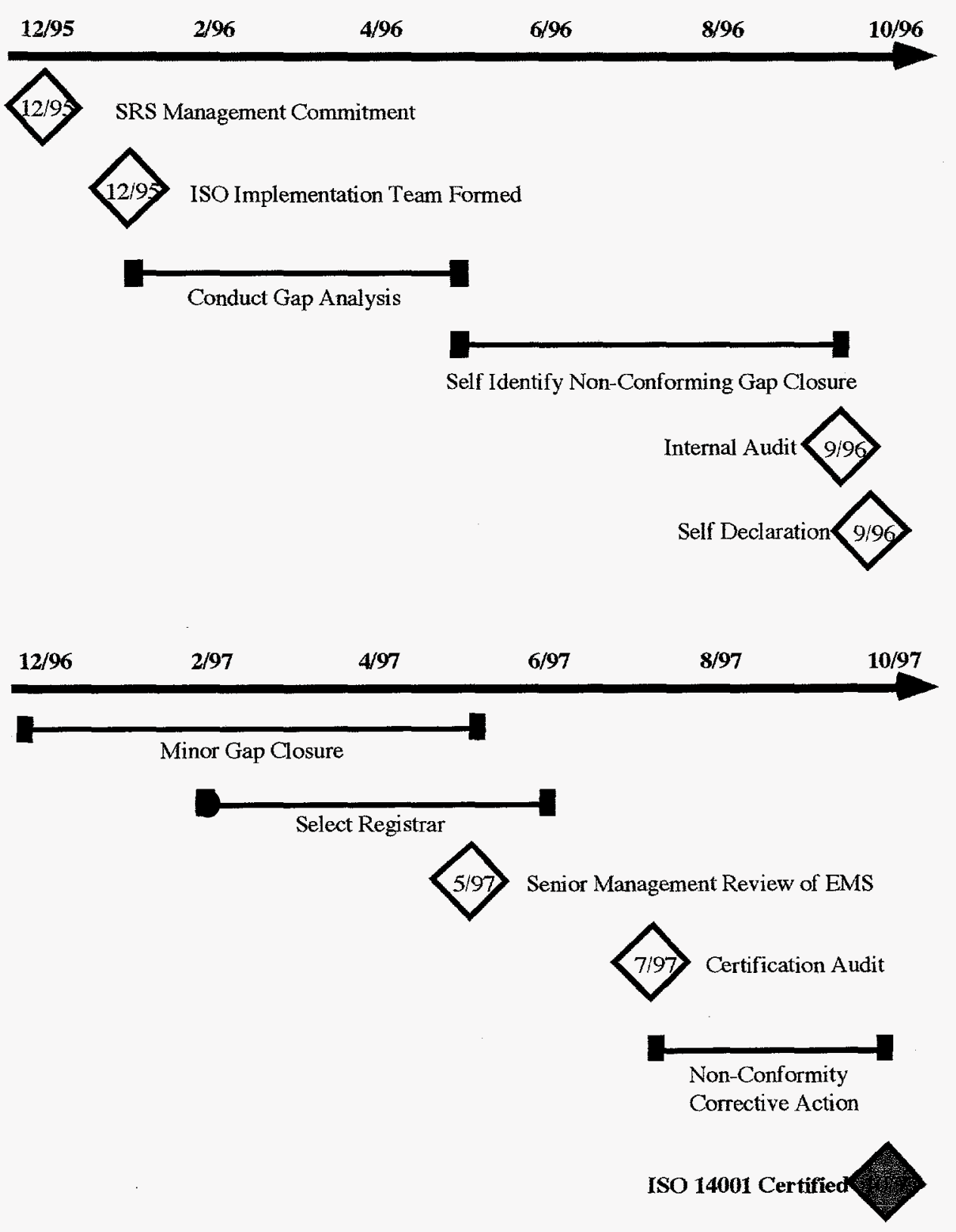

Figure 1. Timeline for Implementation of ISO14001 at the Savannah River Site. 
- Management Review - Development of procedures that establish routine periodic senior management review of the environmental management system was needed.

From June until September 1996 SRS worked to complete the above actions to conform to the ISO14001 standard. The existing ISO14001 team lead the corrective action implementation. Subgroups were formed to work on individual items such as policy and training.

A site environmental policy statement was adopted and signed by SRS senior management. This policy statement was distributed to all personnel. The policy commits SRS to pollution prevention, regulatory compliance, and continuous improvement. The objective of the policy is as follows:

"The objective of this policy is to ensure every employee of the DOE Savannah River Operations Office (SR), all contractors, subcontractors, and other agencies performing work at the Savannah River Site (SRS) do so in accordance with DOE order 5400.1 and the mission, the vision, the core values, and the environmental goals and objectives of the Savannah River Strategic Plan."

A large effort was initiated to provide a roadmap to describe how the documents and programs fit into the environmental management system (EMS). This document includes sections for each of the elements of the EMS. Within each section, key reference and implementing documents are listed. The SRS policy statement is included along with a matrix of SRS organizational missions and environmental activities and responsibilities. This document was provided to all SRS managers prior to the certification audit (see below).

The most time consuming and intensive effort for implementation was employee awareness training. While SRS employees certainly consider environmental stewardship in their day to day activities, an understanding of the relationship of their activities to the environmental management system (EMS) and to ISO14001 was needed. Each employee was expected to know that site management had committed SRS to good environmental stewardship and to know the environmental aspects of their job. All personnel received a briefing on ISO14001 and received a copy of the SRS policy statement that also included questions and answers on ISO14001. Job specific training was also provided that was intended to make personnel think about the environmental aspects of their job. A matrix similar to that shown in Figure 2 was used to initiate discussion. Personnel were asked to list the activities they perform or the service they provide. The potential environmental aspect of that activity and then the potential environmental impact of that activity were then also listed. This exercise allowed employees to think about their jobs and how their jobs may have an impact to the environment even if they do not perform field activities (e.g. engineering, budget planning, etc.). 


\begin{tabular}{|l|l|l|}
\hline \multicolumn{1}{|c|}{$\begin{array}{c}\text { Activity/Product/ } \\
\text { Service }\end{array}$} & \multicolumn{1}{|c|}{$\begin{array}{c}\text { Potential } \\
\text { Environmental } \\
\text { Aspect }\end{array}$} & $\begin{array}{c}\text { Potential } \\
\text { Environmental } \\
\text { Impact }\end{array}$ \\
\hline Shipping crude oil in tanker & Oil spill & $\begin{array}{l}\text { Water pollution, dead } \\
\text { birds, fish, etc. }\end{array}$ \\
\hline Manage high-level waste & $\begin{array}{l}\text { Release high-level waste } \\
\text { to the environment }\end{array}$ & $\begin{array}{l}\text { Soil, air and water } \\
\text { contamination. } \\
\text { Adverse health effects. }\end{array}$ \\
\hline Equipment decontamination & $\begin{array}{l}\text { 1) Waste generation } \\
\text { 2) Reuse of equipment }\end{array}$ & $\begin{array}{l}\text { 1) Waste disposal } \\
\text { 2) Reduce disposal, } \\
\text { save resources }\end{array}$ \\
\hline
\end{tabular}

Figure 2. Environmental Aspects Matrix.

\section{CERTIFICATION PROCESS}

In September 1996, SRS made a self declaration that they were in compliance with the ISO14001 standard. An internal audit was performed with assistance from personnel from other government owned, contractor operated (GOCO) DOE sites to provide an independent review of the SRS program prior to self declaration.

During the first several months of 1997 activities were completed to close the gap on ISO14001 conformance. This included completion of employee awareness training and distribution of the EMS description document. Also, in the first part of 1997 the process for selection of a registrar for certification was initiated. Prior to selection of the registrar, all bidders visited SRS to discuss the scope of certification, receive a tour of the site, and review procedures for submitting bids to SRS.

In May 1997, SRS senior management performed a review of the EMS to ensure the current policy was still applicable and that selected targets and objectives were adequate for an effective EMS. A registrar was selected in June 1997. These independent certified auditors then visited SRS to receive documentation describing site activities and to conduct a pre-audit review to allow SRS personnel to become familiar with the process. One of the facilities selected for this pre-audit review was the Defense Waste Processing Facility (DWPF).

In July 1997, the certification audit was conducted. Facility contacts were assigned to accompany auditors to the field and assist with the logistics of arranging interviews, documentation reviews, etc. The pre-audit review conducted in June was extremely valuable in allowing SRS to prepare for the certification audit in these areas. The auditors reviewed documentation and visited several facilities on site to observe activities and conduct interviews. 
Due to an identified non-conformity, SRS didn't receive certification immediately following the audit. The major non-conformity found was that SRS didn't have an audit program that adequately defined all elements of ISO14001. Several observations were also noted. SRS followed up on the non-conformity by incorporating an audit program for the EMS into the existing self assessment program. New criteria were added to the program to evaluate the EMS and compliance with ISO14001. Following the completion of this action SRS received the ISO14001 certificate in October 1997.

This certificate is good for three years, however, an annual surveillance audit is performed to ensure conformance. The first surveillance audit was performed in February 1998. This audit yielded 14 observations but no non-conformities. If the audit team finds a non-conformance the certificate can be revoked. SRS must also show progress in responding to any observations that are noted. SRS is currently working on the observations noted during the February 1998 surveillance.

\title{
CONCLUSIONS
}

SRS has become one of the first sites in the DOE complex to receive ISO14001 certification. The receipt of this certification validated an almost two year effort. This effort involved an evaluation of existing programs against the standard followed by actions which were needed to bring SRS into conformance. SRS will continue to monitor its performance as an indication of the value ISO14001 implementation.

\section{ACKNOWLEDGMENT}

This paper was prepared in connection with work done under Contract No. DE-AC09-96SR18500 with the U.S. Department of Energy.

\section{REFERENCES}

1. ISO14001: 199X, Environmental Management Systems - Specification with Guidance on Use, Committee Draft Prepared by ISO/TC207/SC1/WG1: February 1995.

\author{
2. D. Sayre, Inside ISO14000 - The Competitive Advantage of \\ Environmental Management, St. Lucie Press, Delray Beach, FL, 1996.
}

